\title{
SORBITOL DEHYDROGENASE ACTIVITY IN SPERMATOZOA OF THE DOMESTIC FOWL, GALLUS DOMESTICUS
}

\author{
G. H. GEORGIEV, V. K. DOKOV AND Z. V. ANGELOVA \\ Institute of Biology and Pathology \\ of Reproduction and Non-Infectious Diseases, Sofia, Bulgaria
}

(Received 20th April 1972, accepted 3rd Fuly 1972)

Polyol dehydrogenases play an important part in the mutual transformation of sugars and polyhydric alcohols in animal tissues and cells, vertebrate spermatozoa being of particular interest in this respect. The biochemical investigations, carried out by Mann \& White (1956), King \& Mann (1958, 1959), Slesingr (1961) and Hankiewicz, Hankiewicz, Hanus \& Szaflarchi (1964), concerned the sorbitol dehydrogenase activity in the spermatozoa of a number of different mammals. The results of these investigations, however, do not explain sufficiently the full significance of the sorbitol dehydrogenase activity in sperm metabolism. The data on polyol dehydrogenase activity in fowl spermatozoa are sparse. Sorbitol dehydrogenase activity in the spermatozoa of the domestic fowl has been investigated chemically by Buckland (1970). No histochemical studies on the localization of polyol dehydrogenase in vertebrate spermatozoa are available in the relevant literature.

The results of parallel biochemical and histochemical investigations on the sorbitol dehydrogenase activity in cock spermatozoa are reported in this paper. The semen was collected twice a week from four cocks of the Plymouth Rock breed, with the aid of an artificial vagina. The pooled material was centrifuged and washed with saline at a $1: 3$ dilution in relation to the initial semen volume. The spermatozoa were resuspended in distilled water and sand was added to grind and prepare the homogenate. The homogenate was centrifuged at 12,000g in a $\mathrm{K}-24$ refrigerated centrifuge.

The sorbitol dehydrogenase activity was determined in the supernatant by the spectrophotometric method of Gerlach (1957) and the photocolorimetric method of Sevela \& Tovarek (1960). The preliminary step in determining the enzyme activity by these two methods involved incubation at $37^{\circ} \mathrm{C}$ for 1 and $2 \mathrm{hr}$, respectively. Protein concentrations in the supernatant were measured by the method described by Lowry, Rosebrough, Farr \& Randall (1951).

The principle of Gerebtzoff (1966, 1968) and Gerebtzoff \& Brotchi (1966) was employed for the cytochemical demonstration of the localization of sorbitol dehydrogenase activity by means of a reduction in vitro of tetra-nitro blue tetrazolium chloride (TNBT-Nutritional Biochemical Corporation, Gleveland, Ohio) by NADH. No substrate was used in the control procedure. The histochemical method was applied in the following manner: unfixed semen smears were incubated for $2 \mathrm{hr}$ at $37^{\circ} \mathrm{C}$ in an incubation mixture of sorbitol, 
TNBT, NAD and tris buffer ( $\mathrm{pH} \mathrm{8.6).} \mathrm{After} \mathrm{incubation,} \mathrm{the} \mathrm{preparations} \mathrm{were}$ fixed in $10 \%$ formalin, washed with distilled water and mounted in liquid paraffin.

The results of these investigations agree with those reported by Buckland (1970) concerning the presence of sorbitol dehydrogenase activity in cock spermatozoa. It has been found that the average sorbitol dehydrogenase activity is $0.61 \mathrm{mU} / \mathrm{mg}$ protein $/ 10 \mathrm{~min}$ (Gerlach, 1957) and $0.18 \mu \mathrm{mol}$ fructose/ $\mathrm{mg}$ protein $/ 2 \mathrm{hr}$ (Sevela \& Tovarek, 1960). The mean values have been obtained from three different samples of pooled material.

The cytochemical investigations have indicated that the sorbitol dehydrogenase activity is localized chiefly in the mid-piece of the spermatozoon, though the intensity of the reaction was not very marked. The formazan granules were localized and outlined the mitochondria. The granules were also observed faintly distributed in a linear fashion along the head of the spermatozoon. The perforatorium and the tail did not reveal any enzyme activity.

The pathways of carbohydrate metabolism in cock spermatozoa have been discussed in the literature: Lake, Lorenz \& Reiman (1962), after confirming the observation of Lorenz (1958) on the ability of cock spermatozoa to transform glucose into fructose, put forward the suggestion that sorbitol might be an intermediary agent in this transformation. Buckland (1970), who established that the activity of phosphohexoisomerase is about seventeen times as active as sorbitol dehydrogenase in cock spermatozoa, assumed that glucose could be transformed into fructose through isomerization more rapidly than through the sorbitol pathway.

On the basis of existing data, the transformation of glucose into fructose in cock spermatozoa might be simultaneously achieved by both mechanisms: through isomerization and through its intermediary transformation into sorbitol.

\section{REFERENCES}

Buckland, R. B. (1970) Some enzyme activities of chicken spermatozoa. Poultry Sci. 49, 1638.

GerLaCh, U. (1957) Pathologischer Uvertritt von Sorbitoldehydrogenase ins Blut leberer Kränkungen. Klin. Wschr. 35, 1144.

Gerebtzoff, M. A. (1966) Détection histochimique d'iso-enzymes de la lactate déshydrogénase dans le nerf et le ganglion spinal. C. r. Séanc. Soc. Biol. 160, 1323.

Gerebrzopf, M. A. (1968) Contribution histochimique à l'étude de la lactate déshydrogénase et ses isoenzymes. Path. Biol., Paris, 16, 601.

Gerebtzopf, M. A. \& Brotchi, J. (1966) Localisation et activités d'enzymes oxydo-reducteur dans le nerf et le ganglion rachidien. Annls Histochim. 11, 63.

Hankiewicz, J., Hankiewicz, K., Hanus, S. \& Szaflarchi, J. (1964) Die Aktivitäat der Sorbitoldehydrogenase und der Transaminasen (GOT) und (GPT) in dem Bullenejakulat. Enzymologia, 28, 100 .

King, T. E. \& MANN, T. (1958) Sorbitol dehydrogenase in spermatozoa. Nature, Lond. 182, 868.

KING, T. E. \& MANN, T. (1959) Sorbitol metabolism in spermatozoa. Proc. R. Soc. B, 151, 226.

LAKE, P. E., LoRenz, E. W. \& Rerman, W. D. (1962) Further investigation on the carbohydrate metabolism in cock spermatozoa. Nature, Lond. 194, 545.

Lorenz, F. W. (1958) Carbohydrate metabolism in cock spermatozoa. Nature, Lond. 182, 397.

Lowry, O., Rosebrough, N., FarR, A. \& Randall, R. (1951) Protein measurement with the folinphenol reagent. F. biol. Chem. 193, 265.

MANN, T. \& WhrTE, I. G. (1956) Metabolism of glycerol, sorbitol and related compounds by spermatozoa. Nature, Lond. 178, 142.

Sevela, M. \& Tovarek, J. (1960) Stanoveni SDH. Sbornik thesi sjezdu, NCSAV, Praha, 31.

SLESSINGR, L. (1961) Enzymatický rozbor ejakulatú bykủ a nizkou plodnosti. Sb. čsl. Akad. zeměd. Ved, 34, 727. 